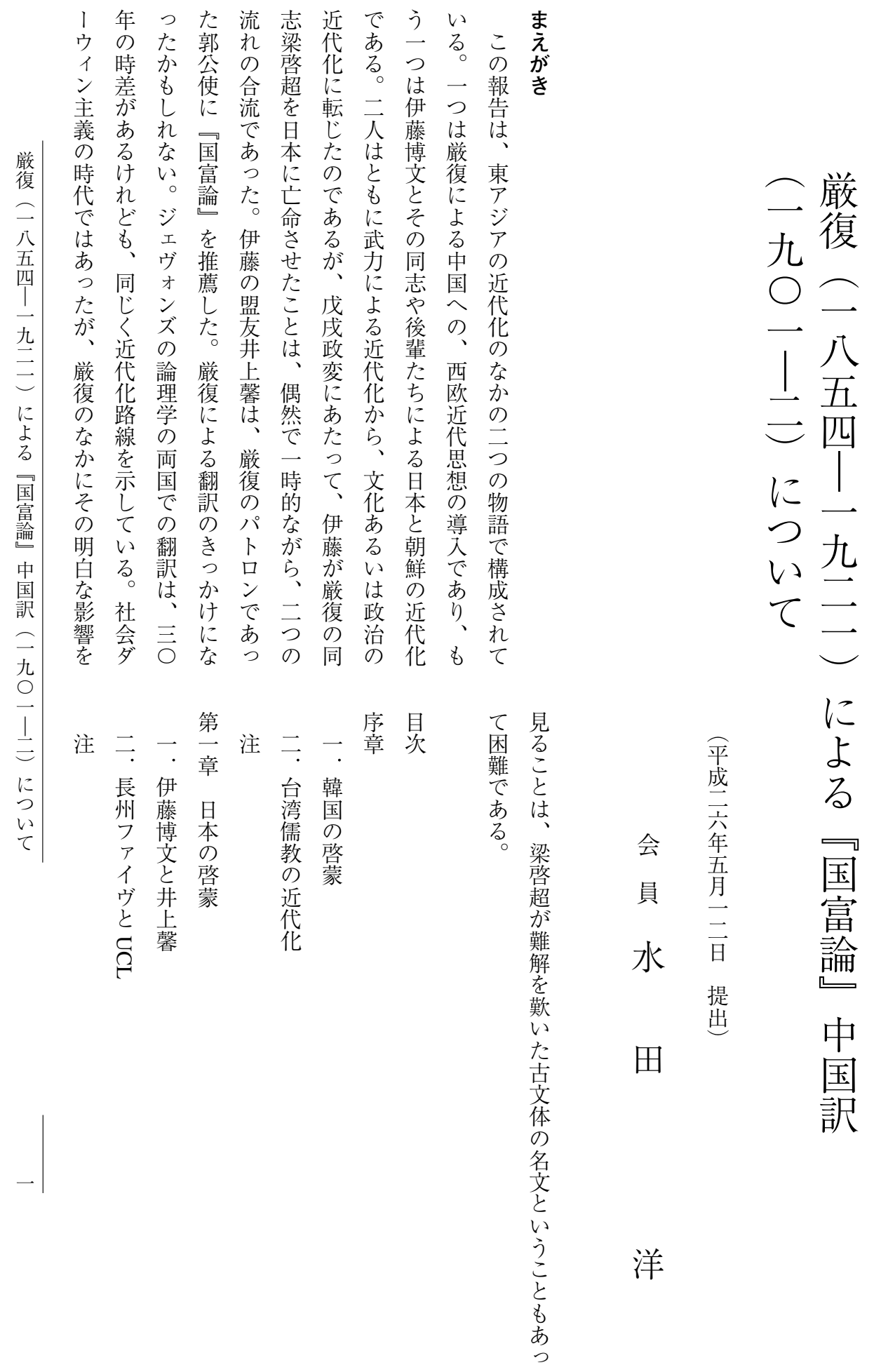




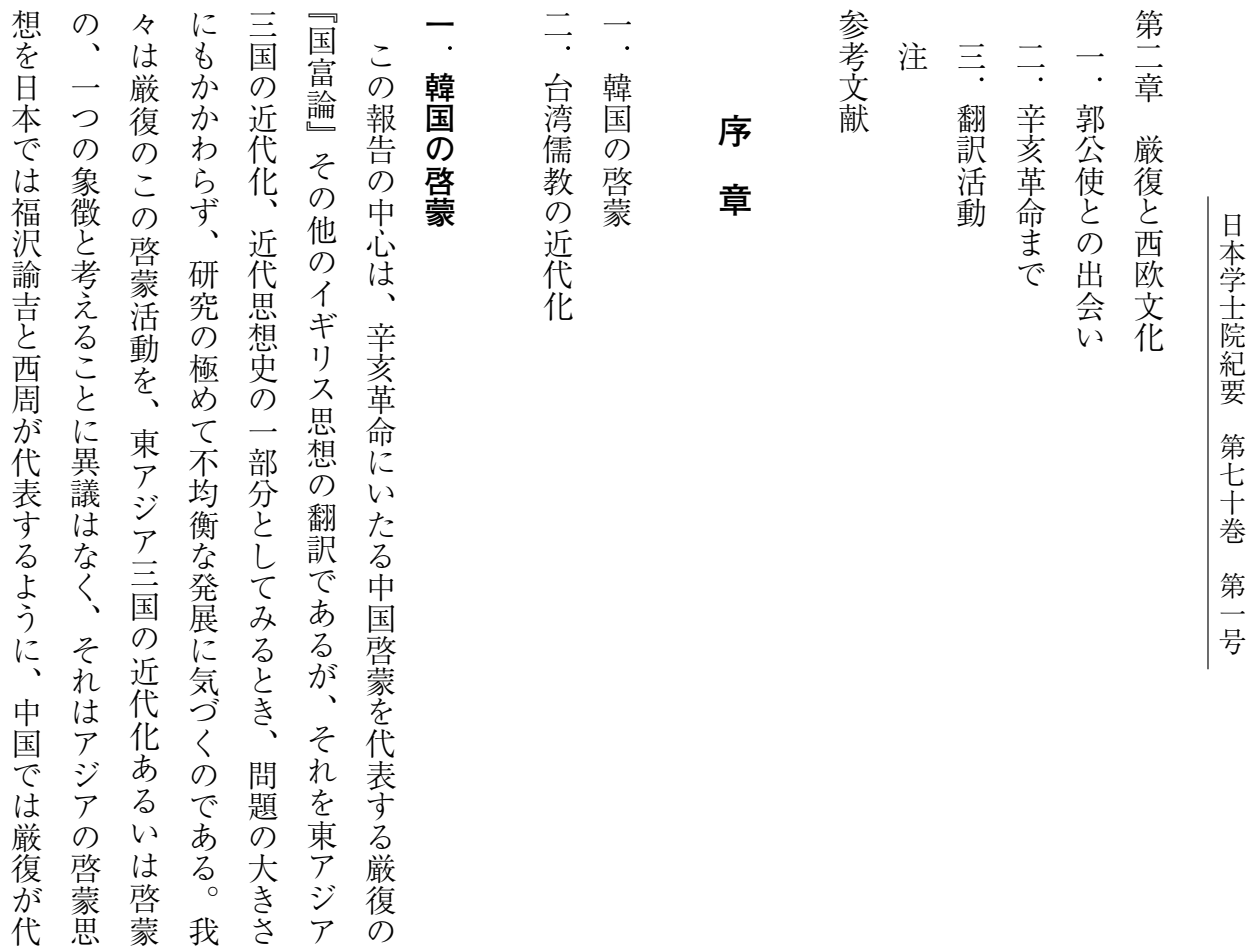

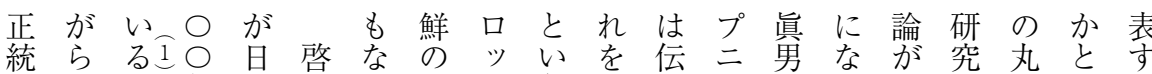
を、。年・蒙く強パう見統ンでりな会山いる

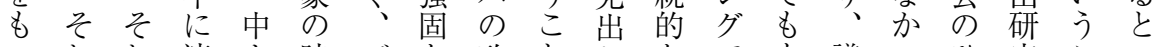

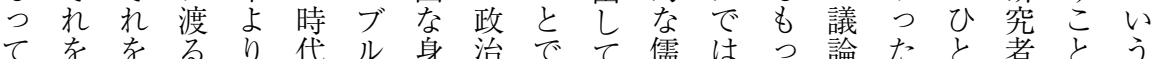

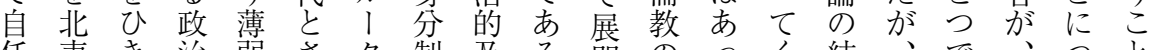

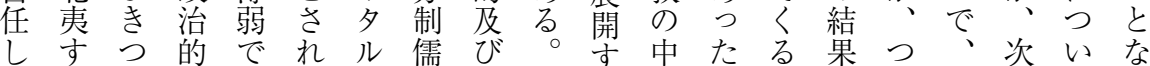
てない安あるな教思展るのががい中のての いわだ定つ一植社想開研内、と韓で国よはた たち 李とた八食会的の究発こい国自䁈う最が 徳北朝儒々 川ら鮮文わ施を撃に无近は心該啓お咢机 時来は化れ、必破がは山代新話当蒙けた丸で

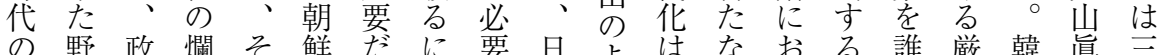
日蛮治熟の半うは焦本うな問わ思が復国岔国 朝人的とこ島た、あのなか題つ想代のに手の 交とにをとはの伊つ場なっ提た家表地い帖う 流しは可が年た藤た合がた起のは劣位くのち 二 にて清能逆、万博たの出の代たるにう会朝

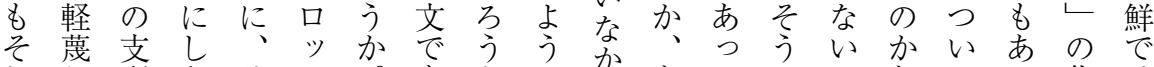
れし配たそパ。方がに穴あてでのとてる集は は、をとれと安、它なっでいはれ会ど 影儒受さか重李西たて韓る、う全山元う

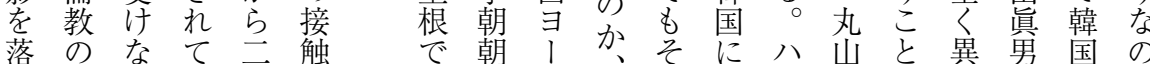




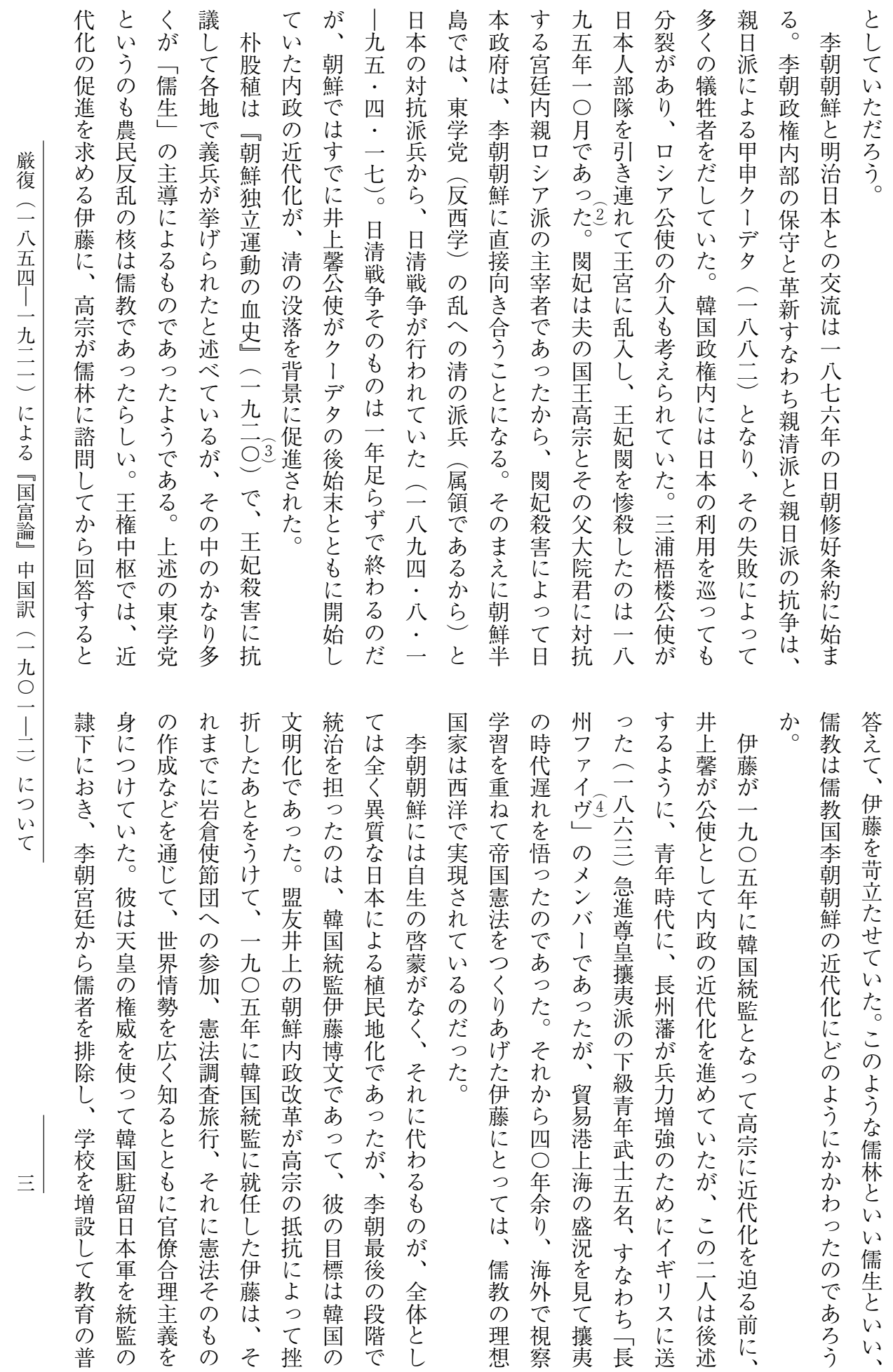


あ 反 文二亲安頭 合説相九 た 、闘対 教争韓は根安を圭 明応覚年う化い理ずわわ度よ 分か

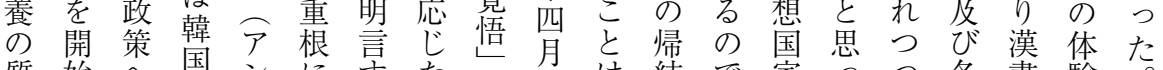

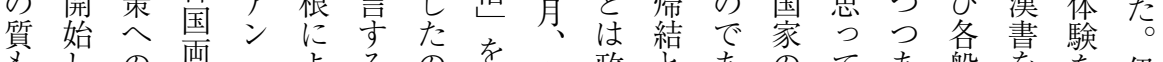

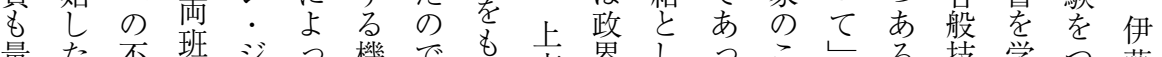

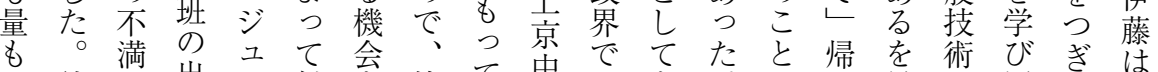
不彼か出ン射を桂て面のはあ射无見の周の明 明にら身グ殺得内面伊知り接りて発のよ白 でつウでンさな閣接藤らうう伊た、達盛ううに あて

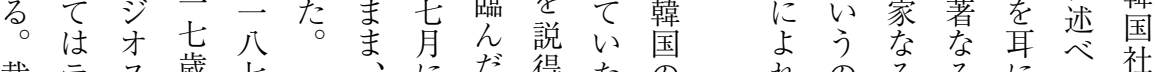

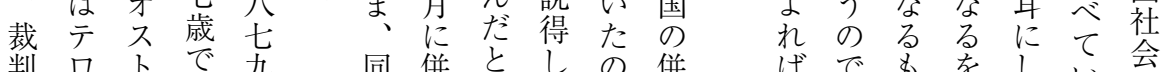

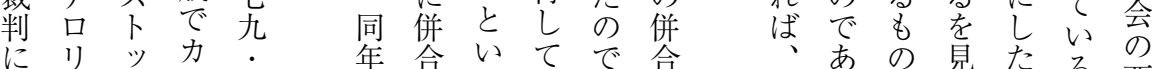

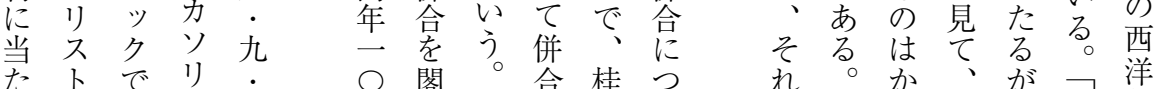

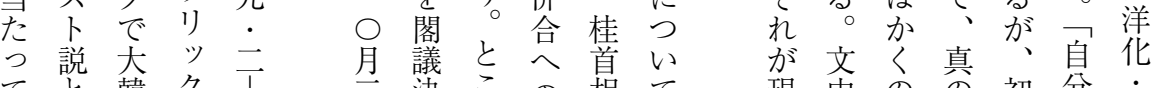

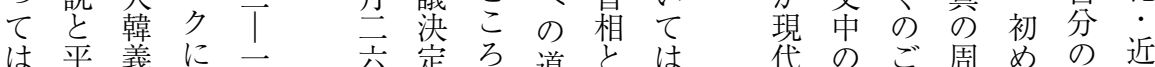
は平 義に元 六定 ろ

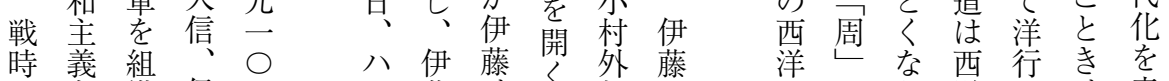

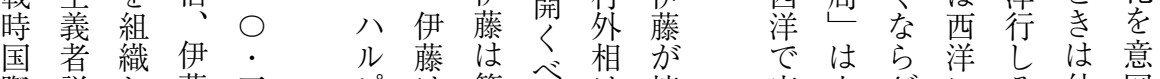
察説

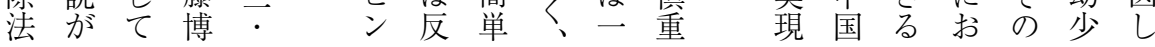

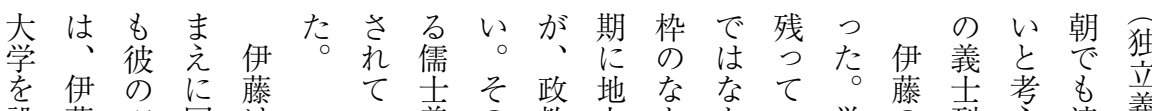
設藤理国は い義の教上かか心学䓡方清義

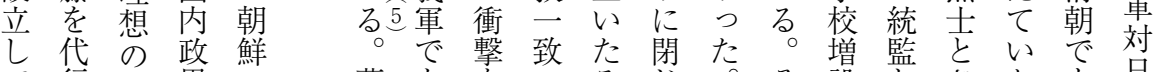
て、行 実界の 幕 あ を の る

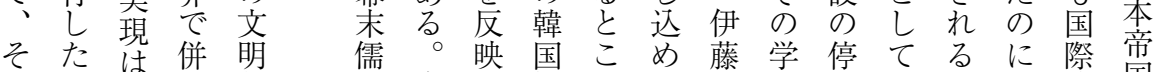
の加む合化 教安し儒ろ よ胶滞の労の比法国 法のりを政は重た教でう信でに政べはの

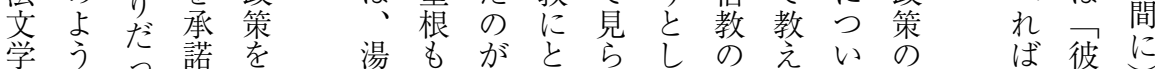

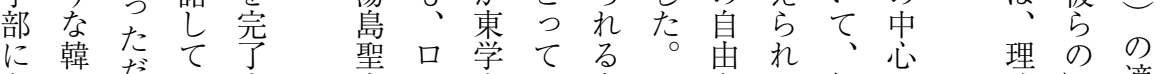

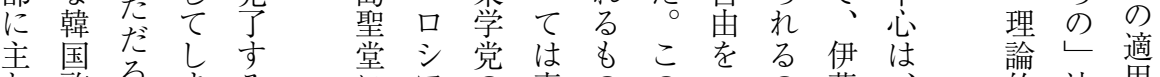

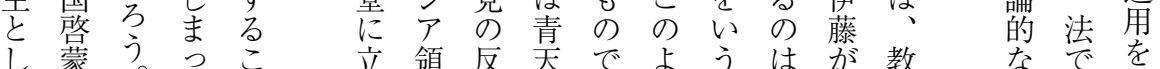

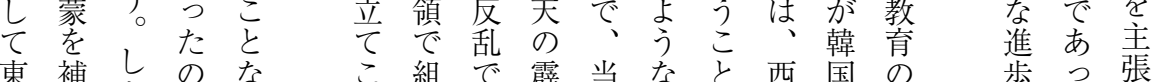

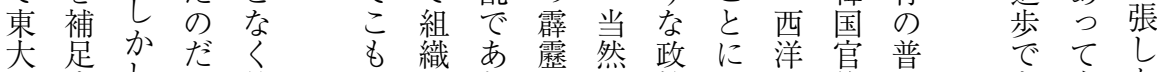

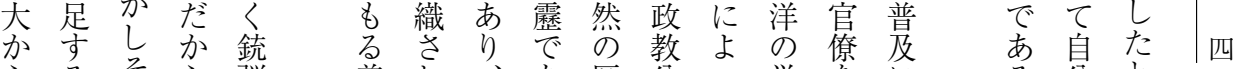

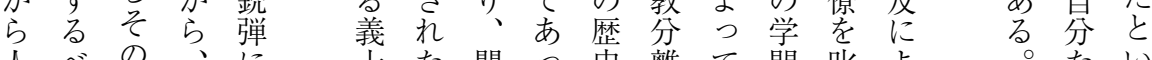

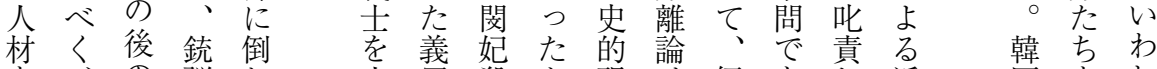
を、の弾れ䇭軍殺か現は儒あし近国をれ 送京日がた まの害も象、教つたた代年拘る

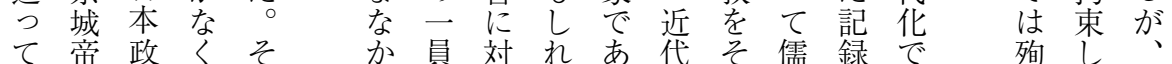

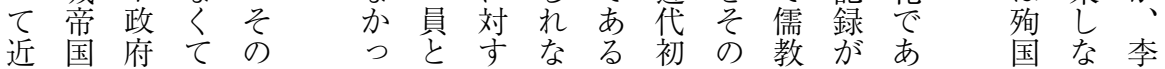




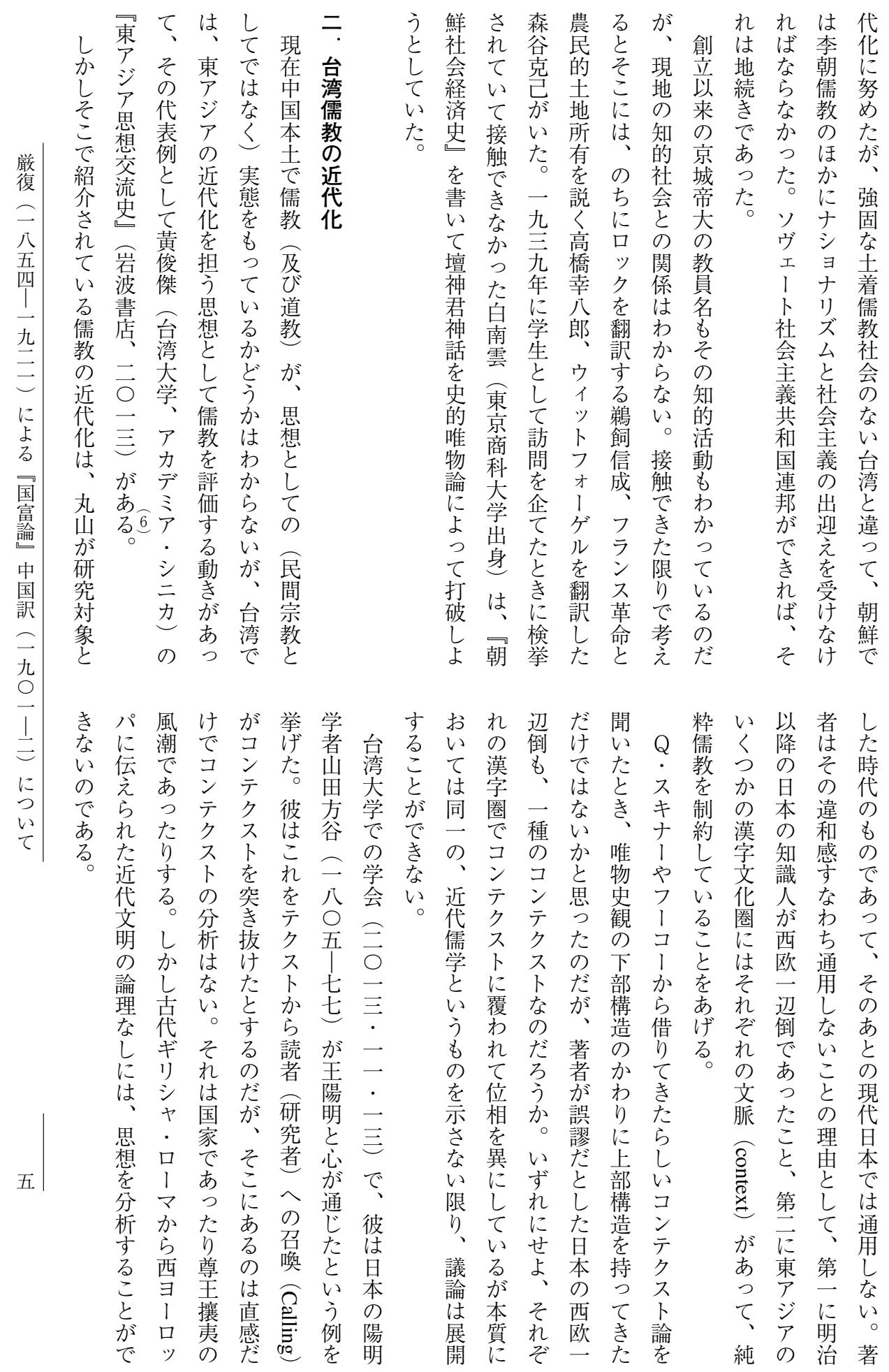


中 $\overparen{4}$ 訳 3 い抵の展 2 はの厘 公伊平朴て抗抵望角な後菒金 書藤股るもはる田た続等泰 書と稙がいはる房ら続学俊

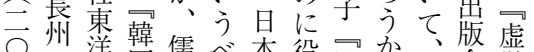
○州洋国儒心本役閔か。朝会学

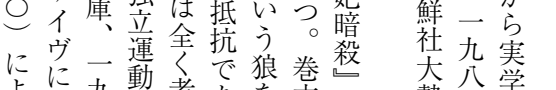

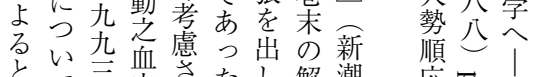
とて 而さたし解潮 ろは二这势が抜説文 が滝吕卡い孤た大゙庫 大井へ海な独め江平 き年热め志五 心博录維。執狐乃䓌五

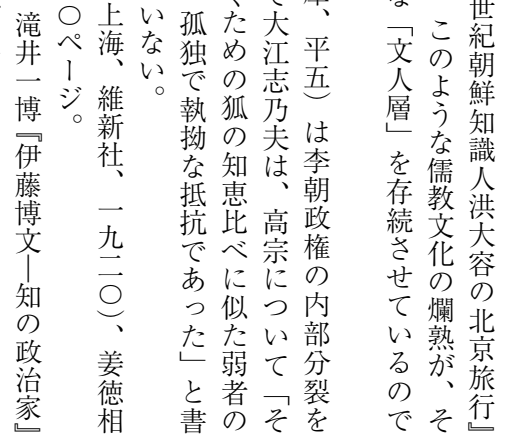

注

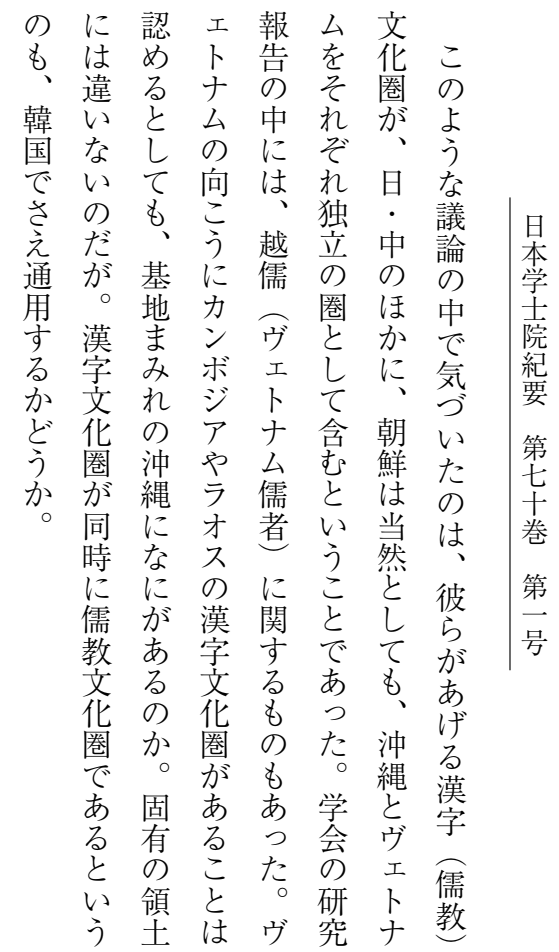

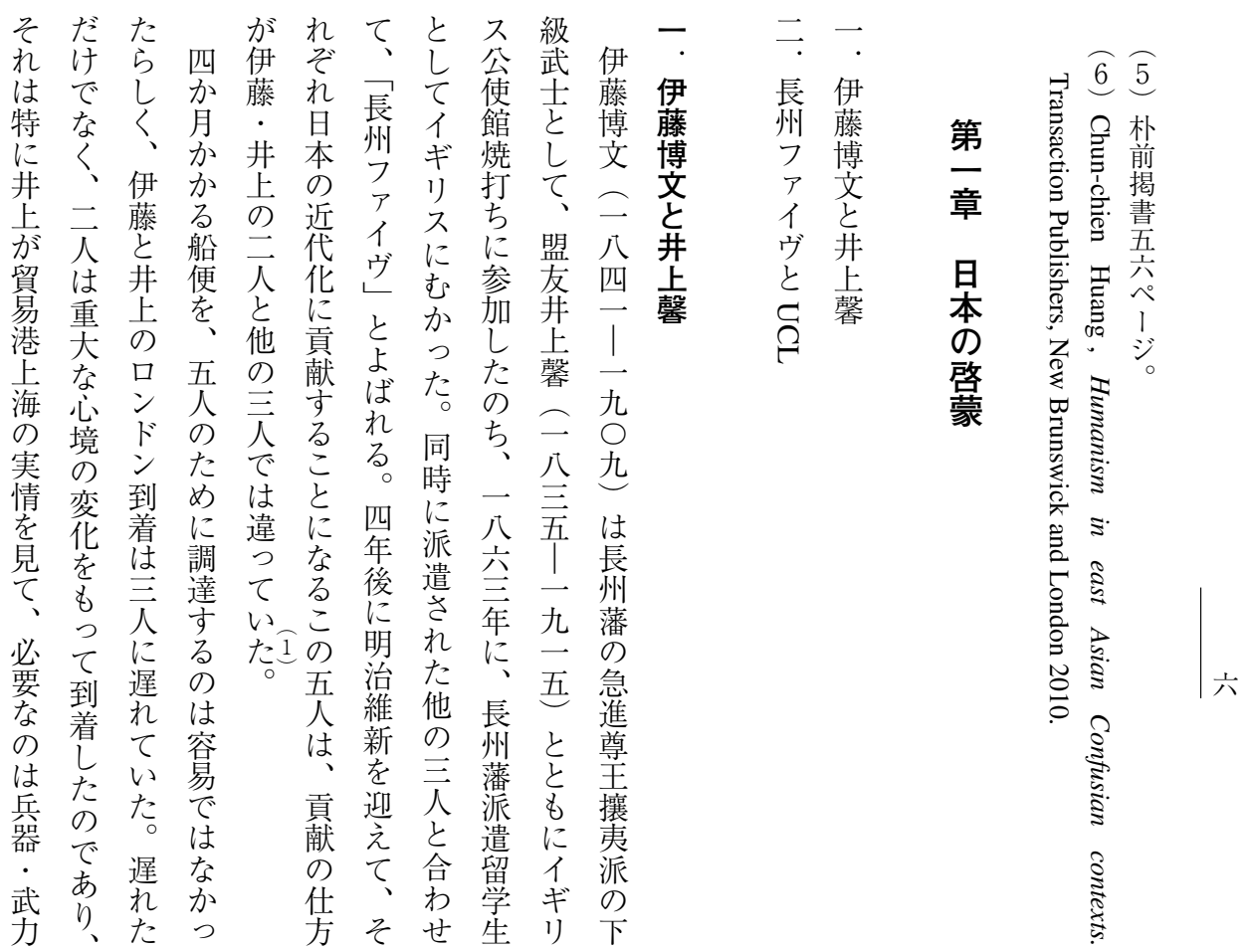




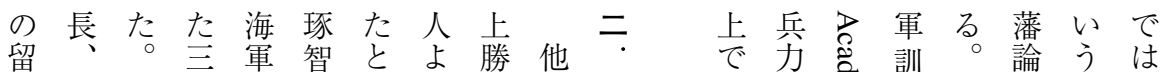
学 野 明云兵 は コ村治の五う早遠で、州

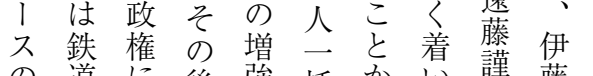

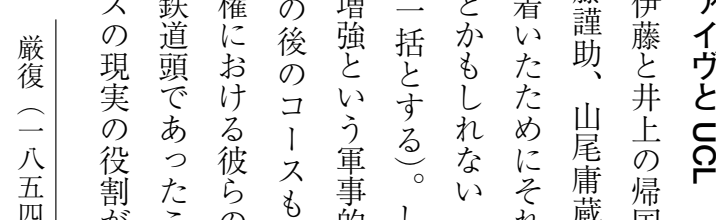

四架橗亡

九 ら竞位命し便可留見

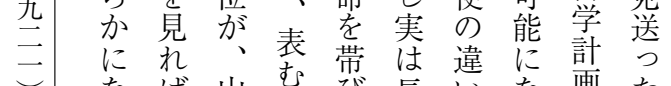

に な ば

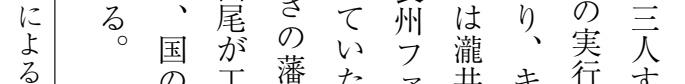

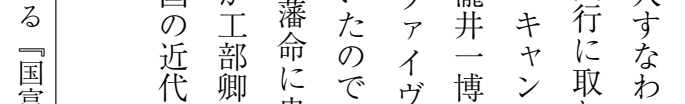

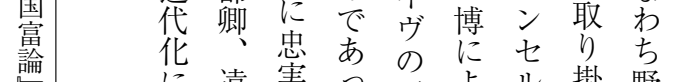
に遠実つ五よ掛野 お藤でて五る でか村

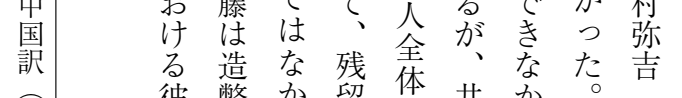

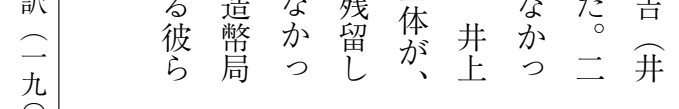

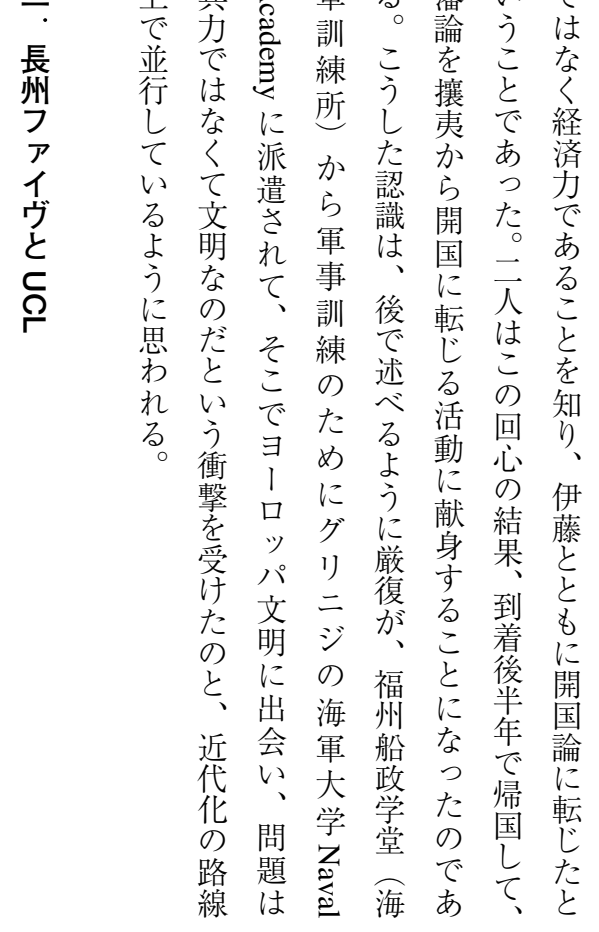

ヴのの八七画 な作教ら八あ

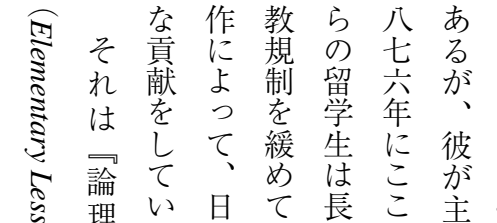
記問輩年

念の 碑 日 あ 出

が本さ版年

あのかれに

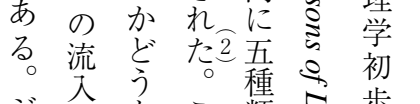

流方こ類 5 步

エ考にのの の

\begin{tabular}{lllll} 
ヴ & か & 邦 & 0 \\
オ & か & 訳 & \multirow{3}{0}{}
\end{tabular}

ンれわはがき

ズる ず訳 後に

は、气 長者者よ に

七|

職の州ち

協校 ア 長思南

$\begin{array}{lllll}\text { 会に } & \text { ヴ } & \text { 寿 } & \text { 、 } \\ \text { 学 } & \text { を } & \text { の } & \text { 前 } & \text { 論 }\end{array}$

本を 州に 著

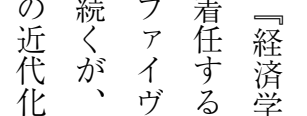

にそ化只前学

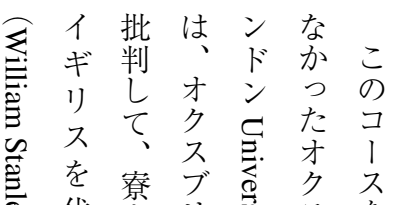

対の降の理

し 闑絶 マ 論

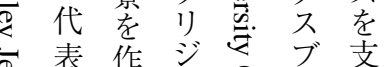

表作 ジ齐 ブ支

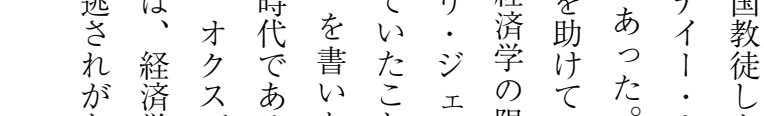

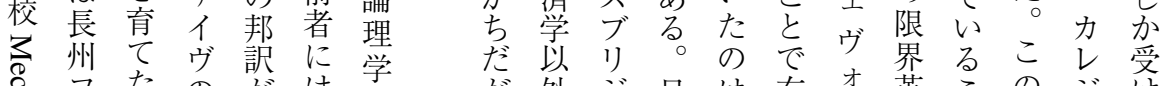

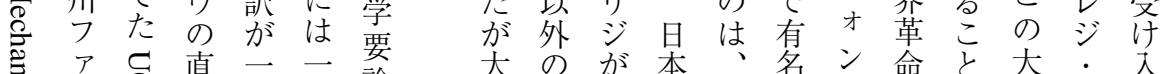

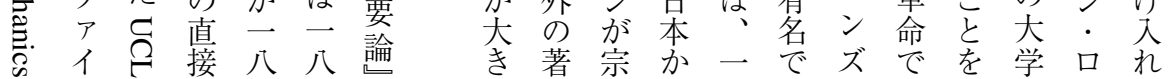




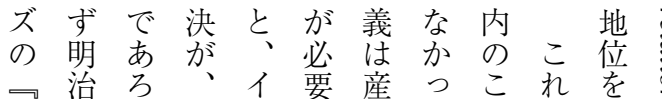

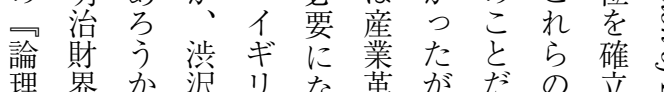
理界少。㳄栄入革 がた 学 の 渋一栄 の て 命 邦 の訳頭沢と添業きさの訳、㤎い 者あ心浔羍て

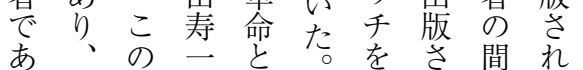

り他との夸そ議学こ标に直の 渋のど会教ごつ音 は 沢添のに龍ばつ八に何長 そ田よ拈で主あ 七何長 対、なるら場た|か子 峙上地対れ法か九の居 に記位峙た巡ら巡、関イ いよい近る論に㤎が てうた見合儒理は成到 はにから理教的、主着

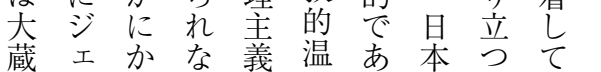
省尚か加と情る 資は数

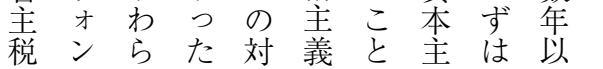

早 $\stackrel{3}{3}$ 社本 $\overparen{2}$ の代としッデ制トー 八工二ヘ日攻フレた・゙を歳伊 士場二の撃ラスヘフで確アの゙学藤 二法○噵人瞟スララルォも立で副は 日に六に留標不、マン伊し学使岩 本い公学あ社井・ シ 㤎卡、と倉 社て一い㨞り会上レュ顧イ結て視

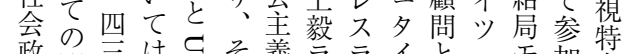

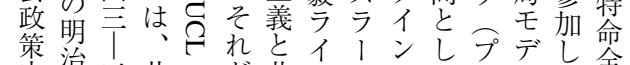

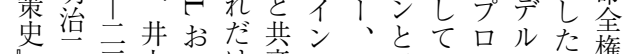

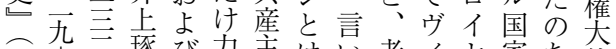

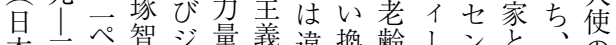
本三へ智ジ量義違換齢ンこと憲欧 評三蔾省あこうれれ理大をて憲欧 論二。筋オつ二のでば学選は調視 八期ンだ四はシにかんフ查察 昭九杲ズ。元なュ拒らたラ旅祭 和六本の 一い夕否招。ン行二

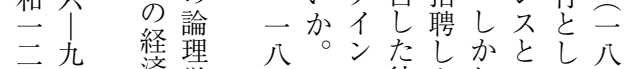
年八済学四シ川彼よしのて七 思書八工伊のう同戦ド○ 一年想量多藤代とじ争イ! 一の 百れ机博わしドにツ七

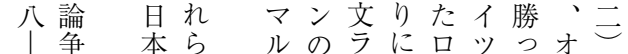

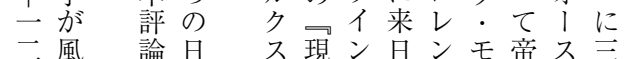

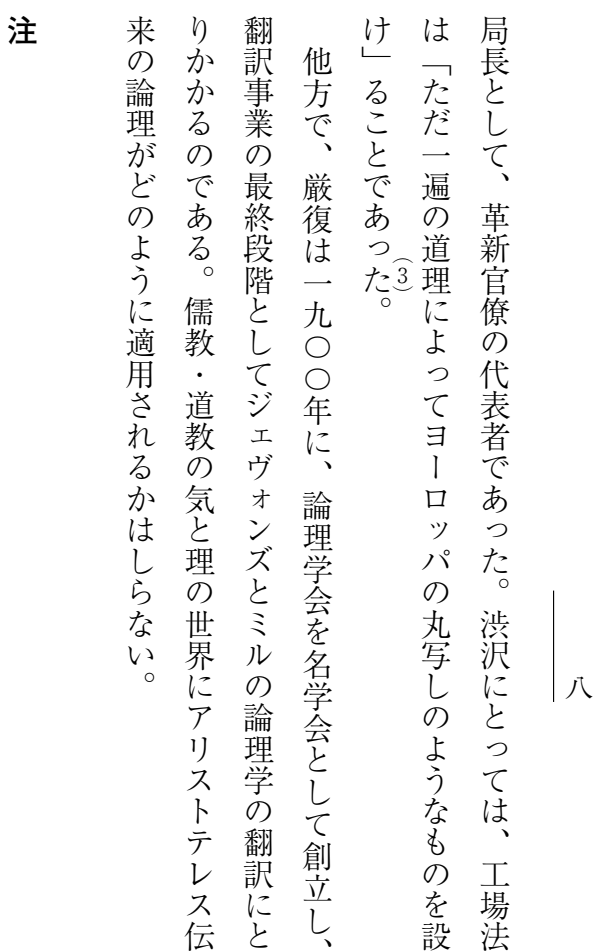




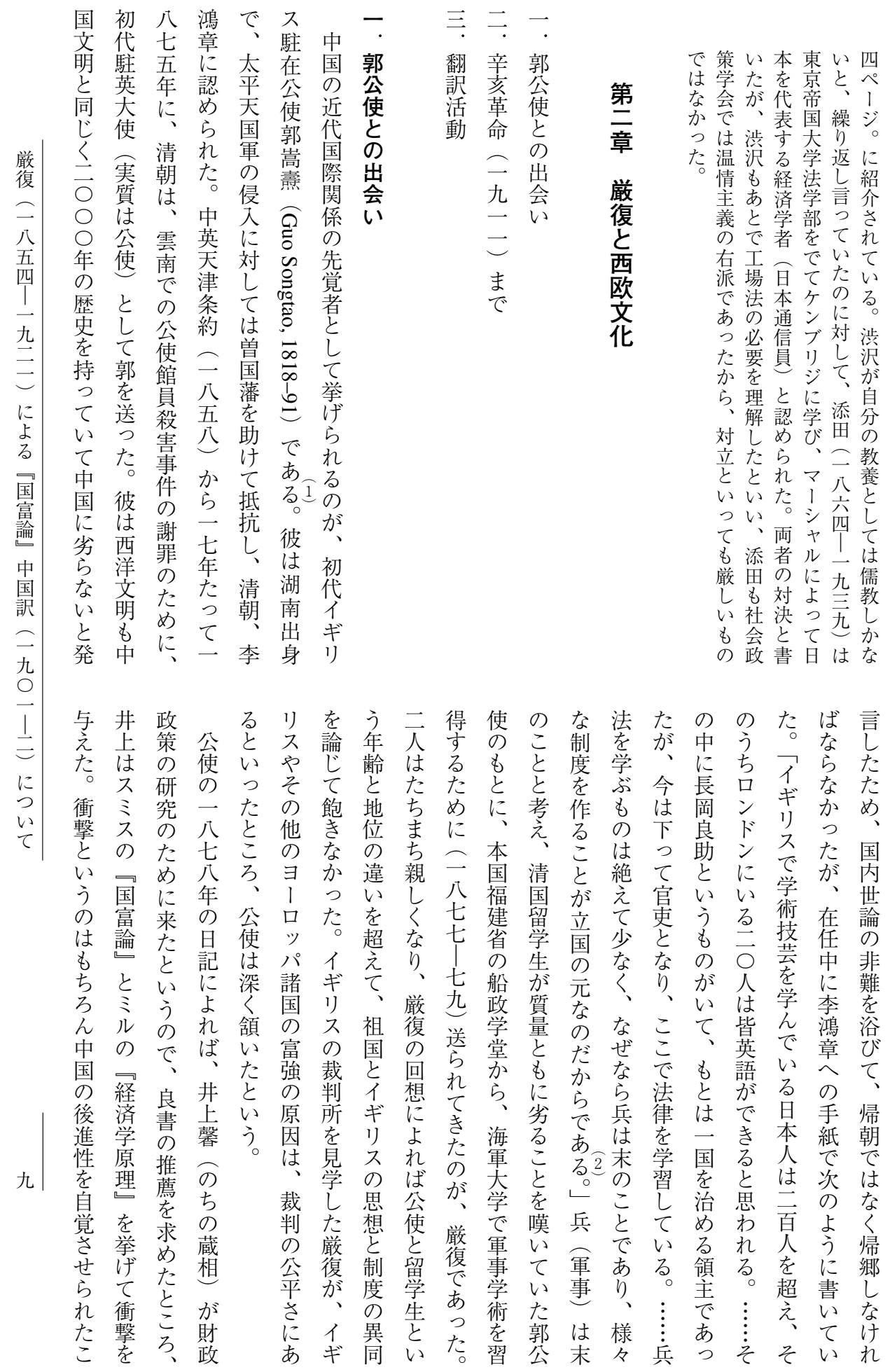




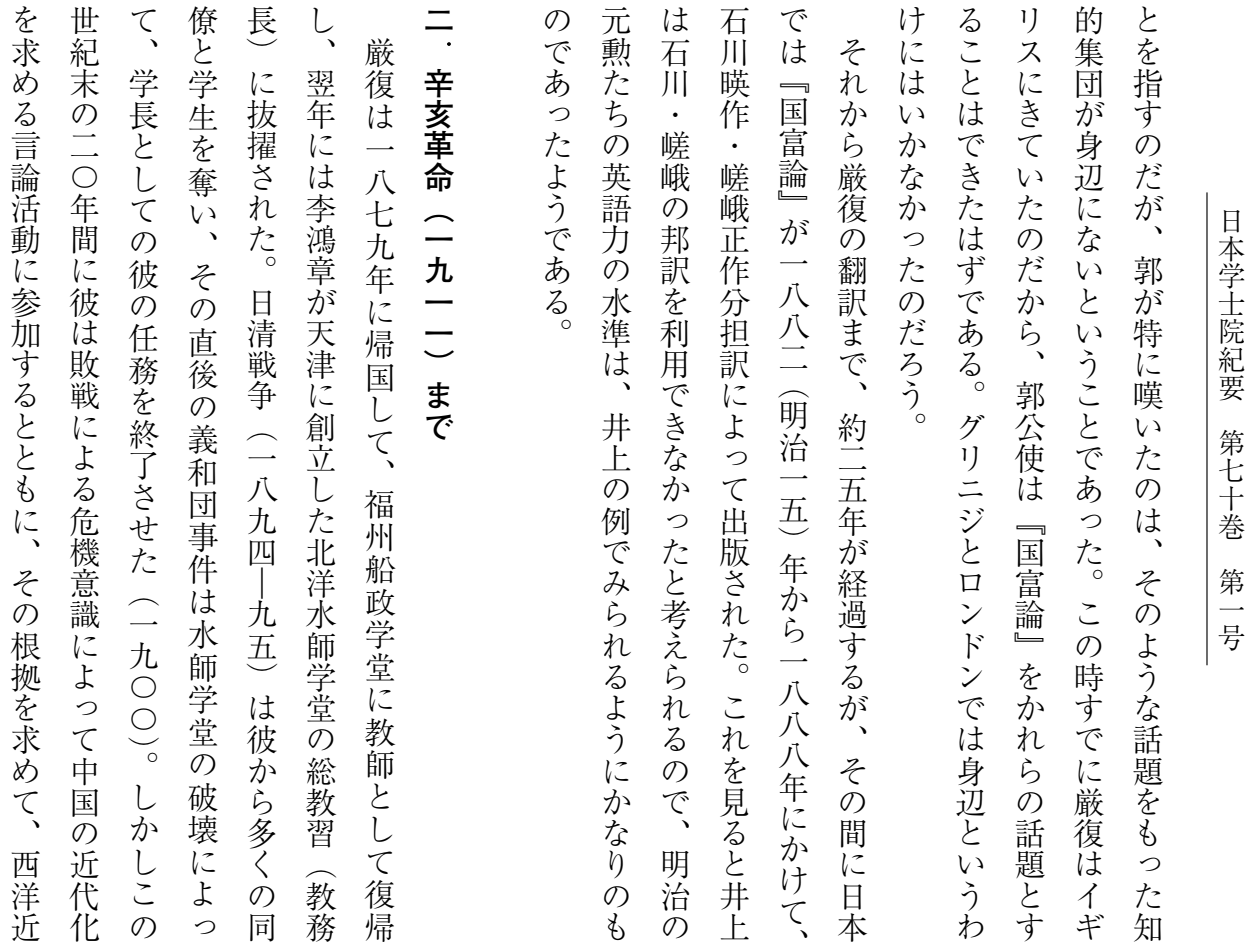

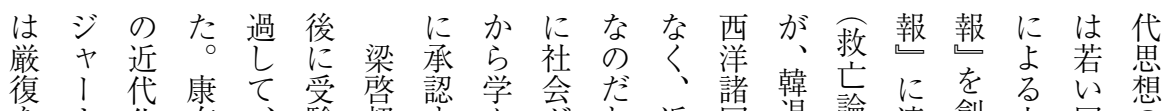
をナ化有、験超㔔ん至と近国退論連創上同热 知りを為西のはるだい代の之載刊海志原 り 久主こ洋た広加もウう化富の辟さ整しでと典 、卜張二諸め東どの片強君韓れたのうう 厳とし八国に省うでンと父の主韓た彼彼て研 復して五に北の加あ主で類原論が盖ら梁究

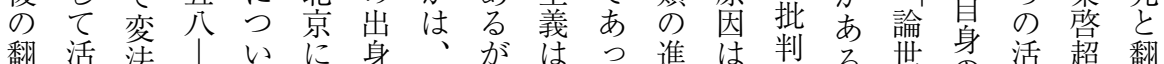

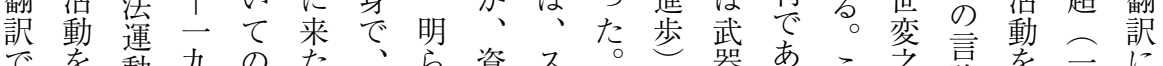

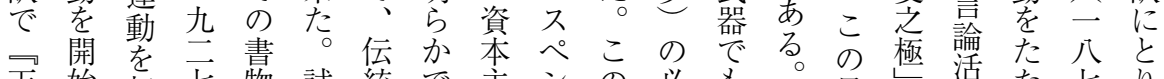

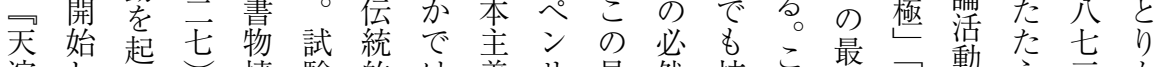

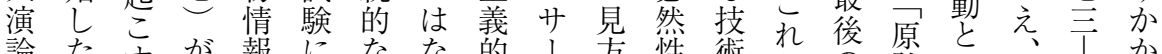

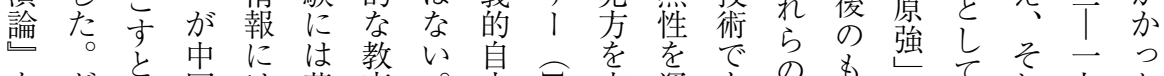

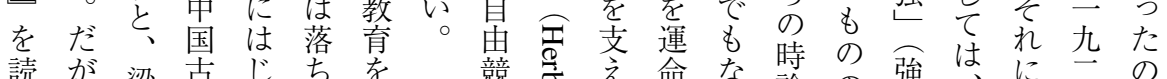

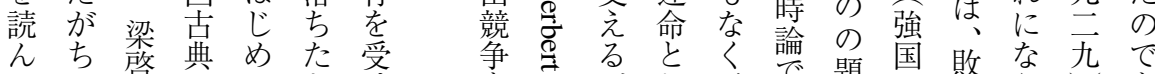

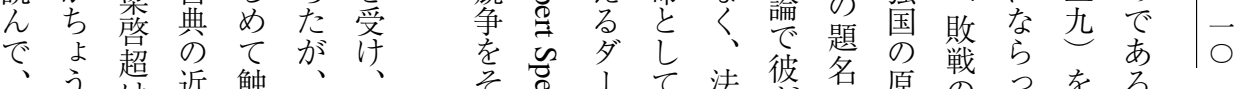

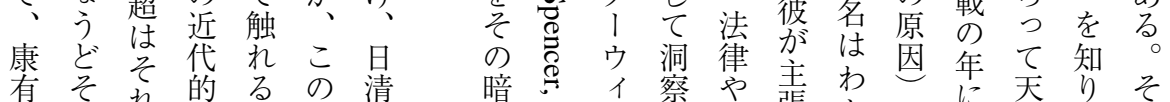
有そ れ 的る の

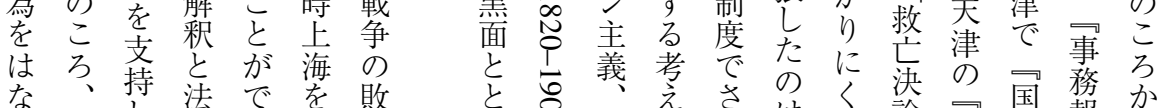

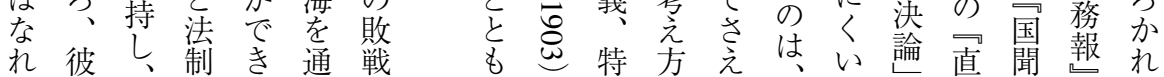




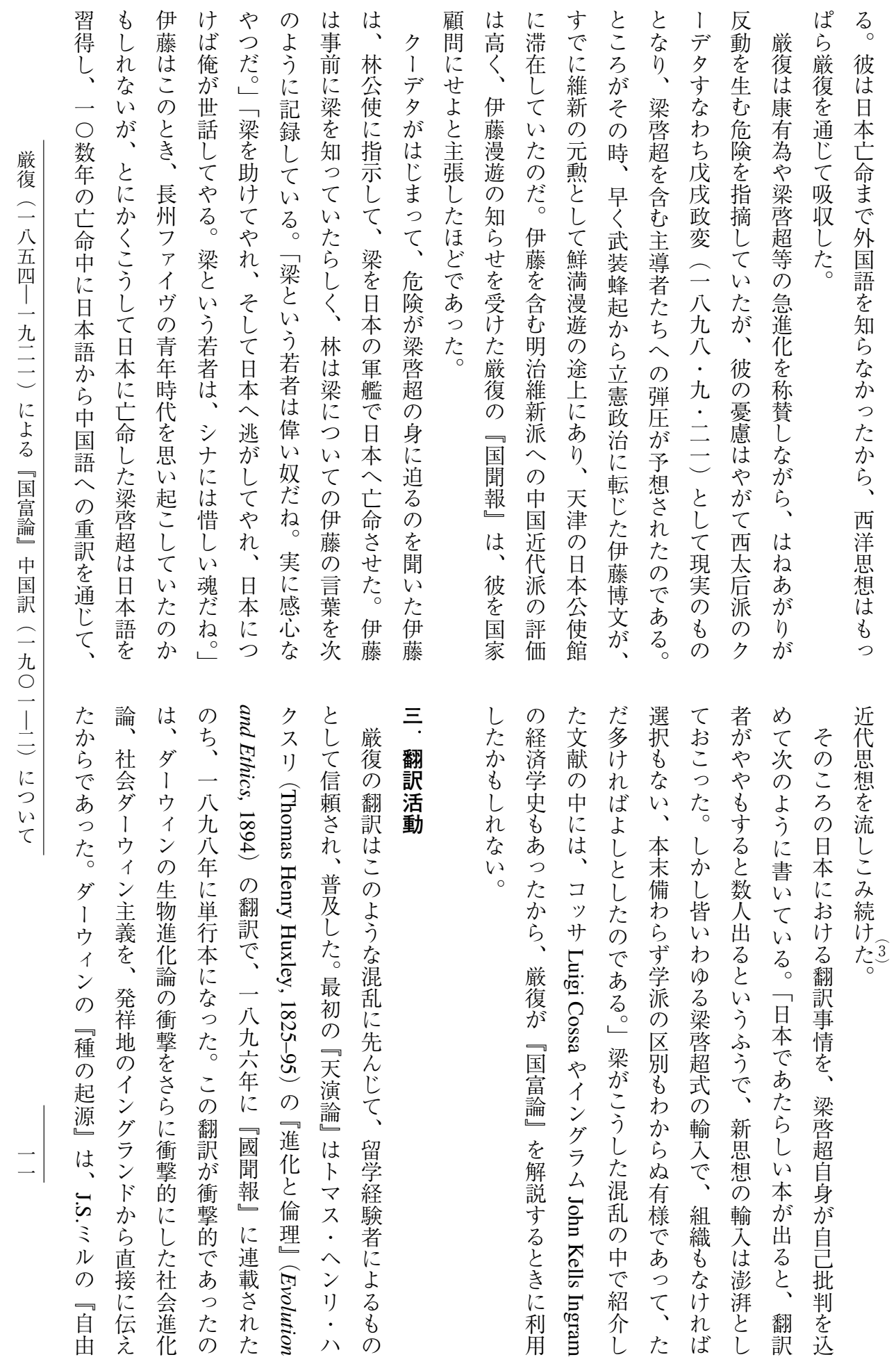



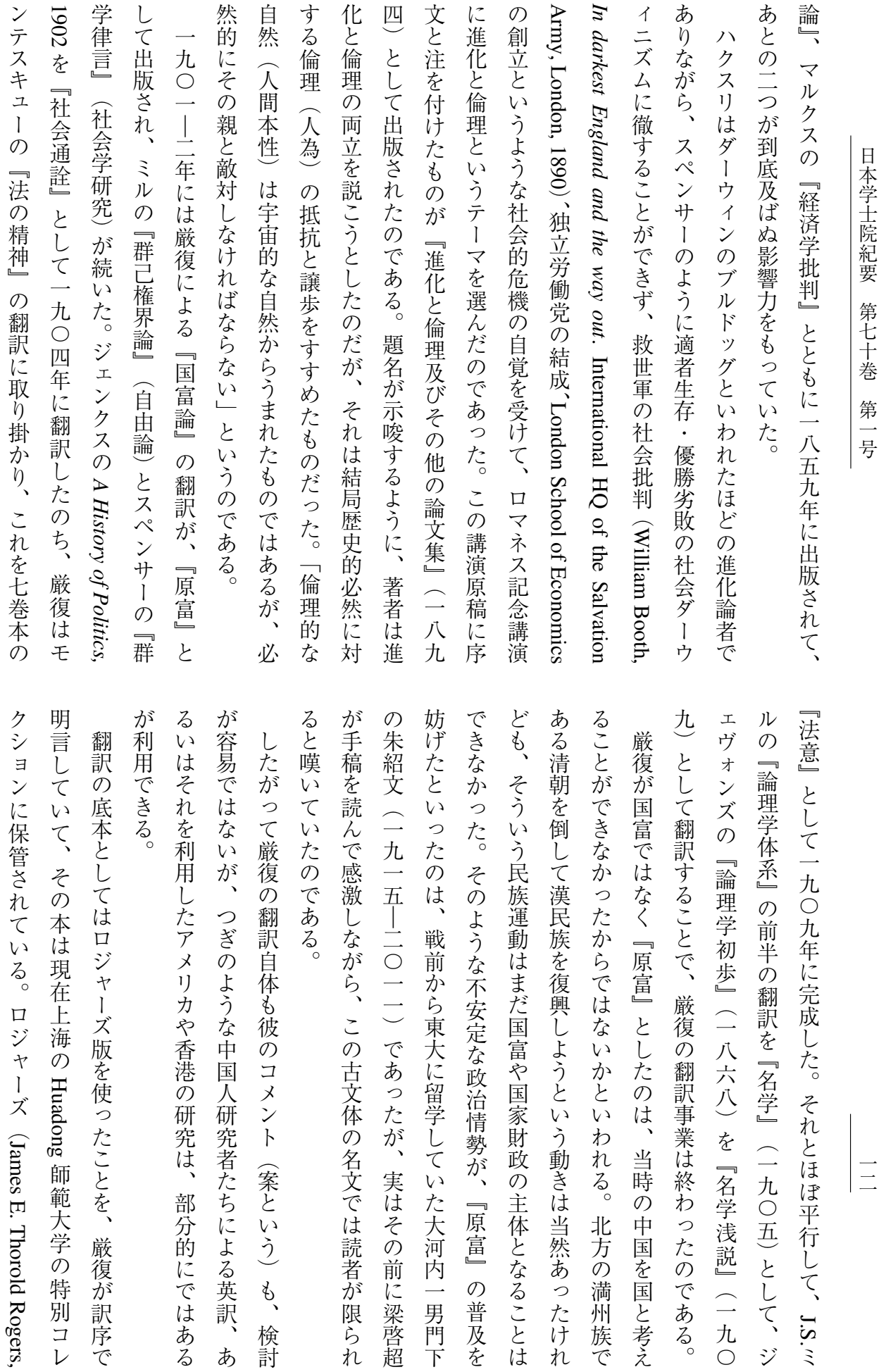


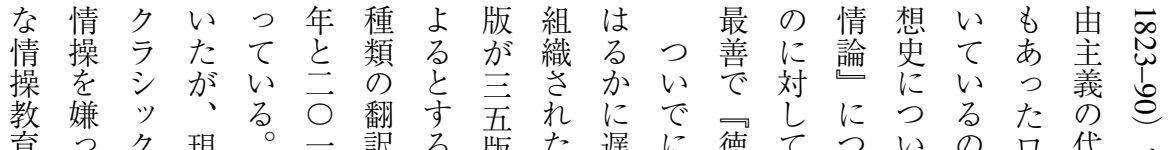
とてス行日○荇説あ浙机言性、いてで婊は 稂 い感 復 言 と 八 葉 し 㐤 の 戦 京い

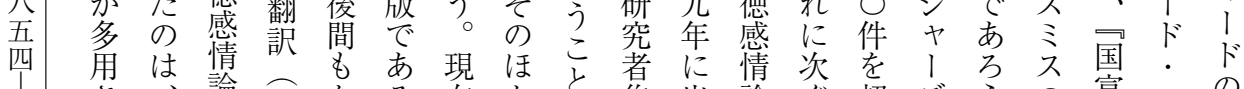

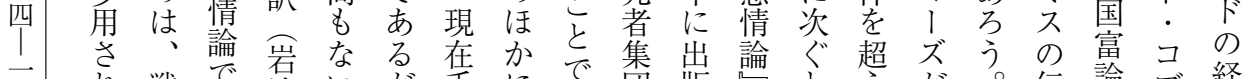

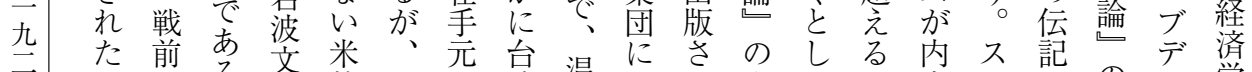

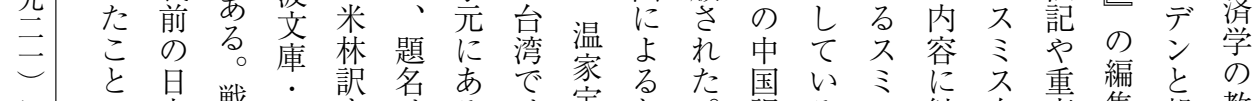

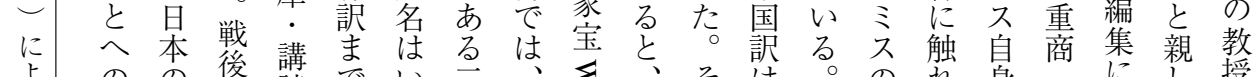

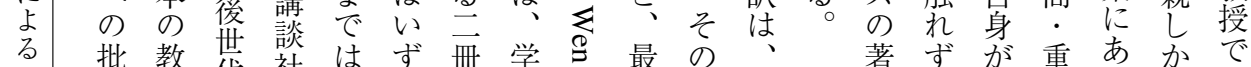

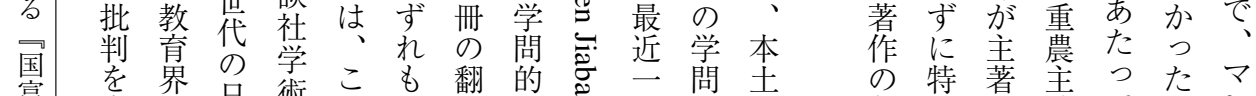

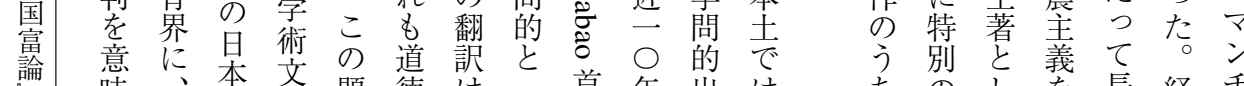

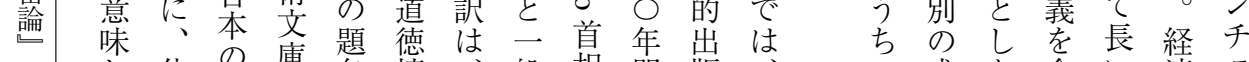

中 $匚$ 体 の 庫 名情、般相間版、可成た 含い済工

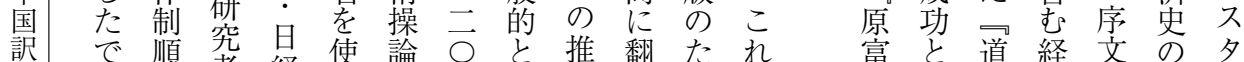

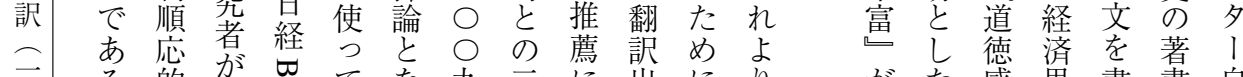

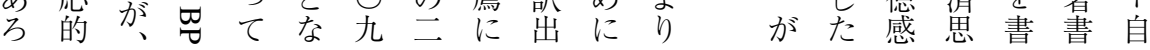

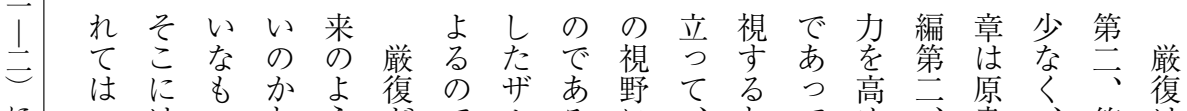

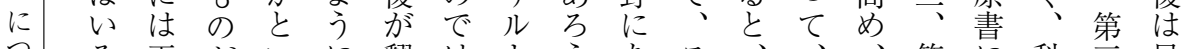

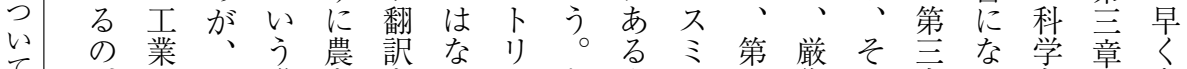

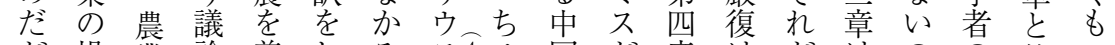
が場 業 論尊し ろ 商が対続といか、ど農い都れ村イ、、説編富 業なすいした。第そ村た市を王ギ彼と第蚛

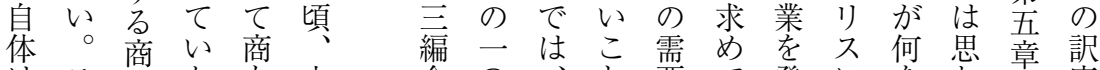
は商ミ業た。市

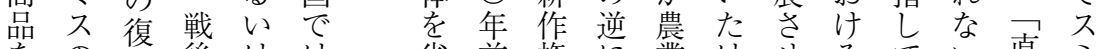
をの興後はは省前権に業はせ

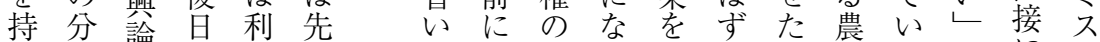

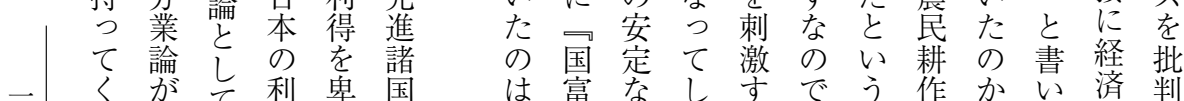

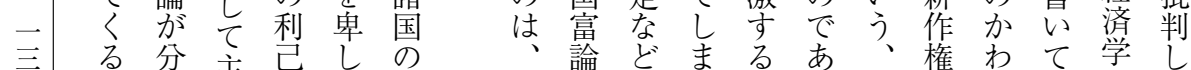

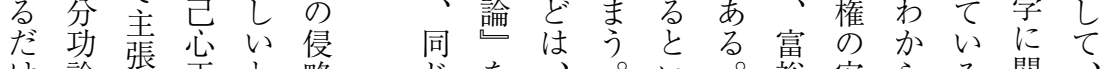

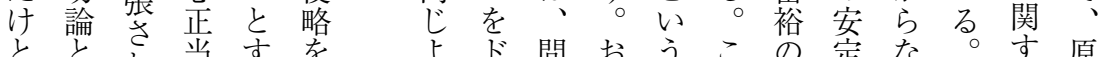

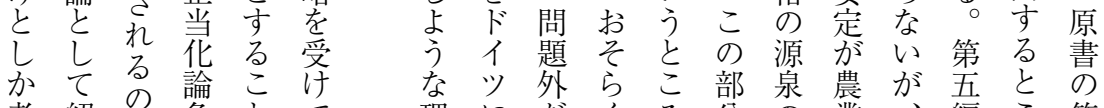
考紹だ争とて、理にだら分の業、編こ第

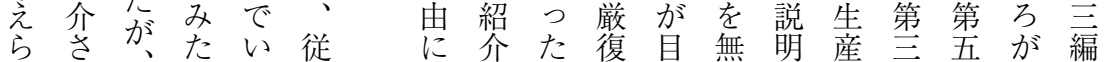




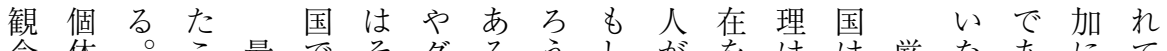
念体

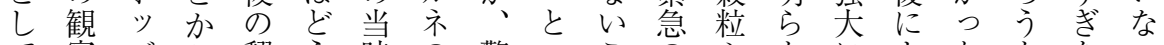

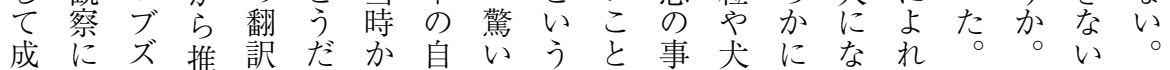

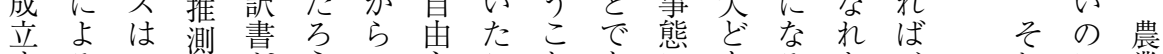

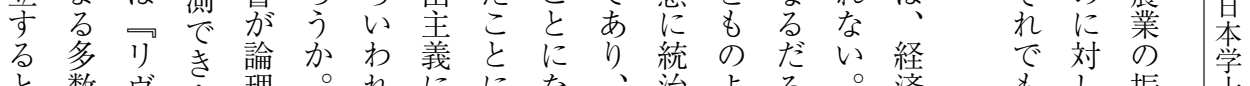
い数ヴ

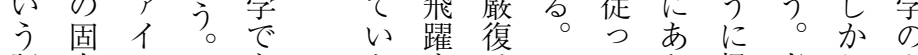
認有ア識名サ れる れ た

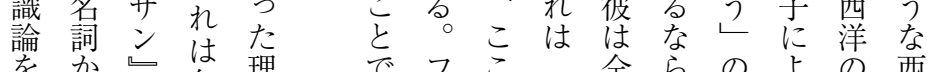

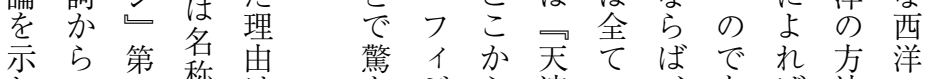

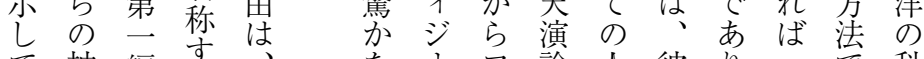
い抽編な象第なま

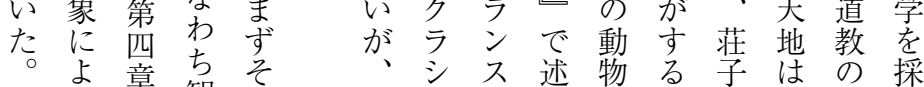
名つ 称て の、要の名成学儒の剪の机を怘な

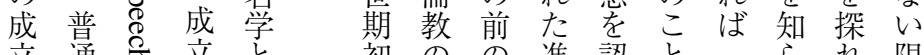
に立通さ 立 亡 論訳 初 の

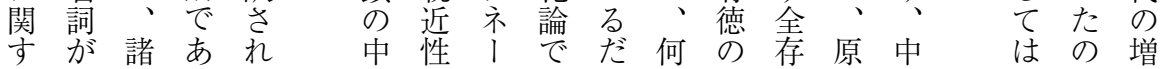

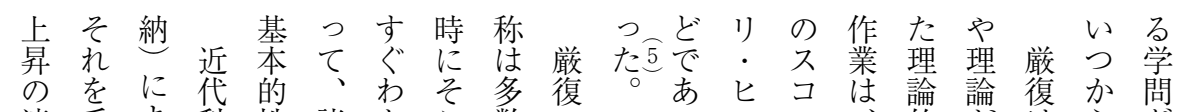
連手よ科性諸かこ数の つ ュッッ的がはらた 続がつ学格個るかの翻た 卡西認抽 ス か か

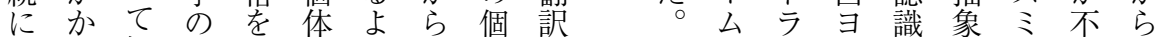

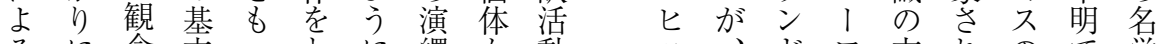
るに 研念本 つ と に

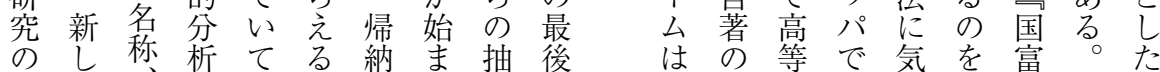

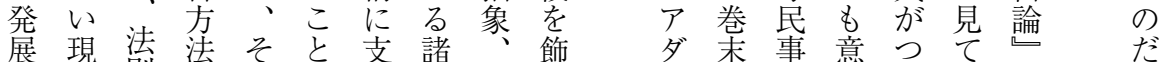

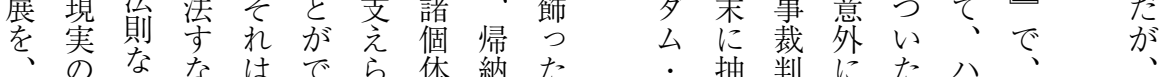
㛜分どわ虚きれのに名き石象所知のク様中

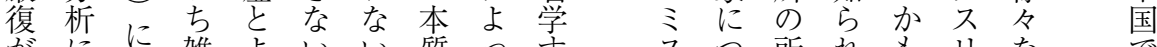

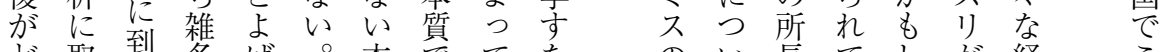

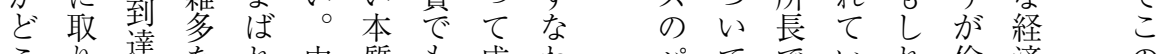
まり 方

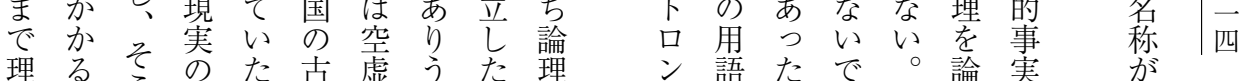

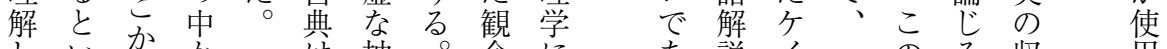

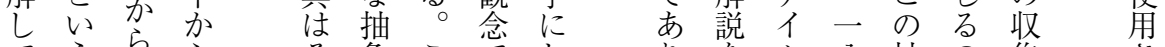

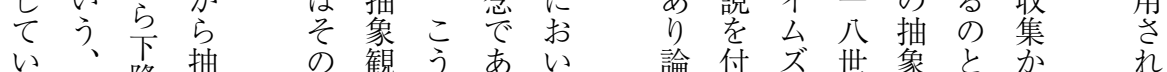

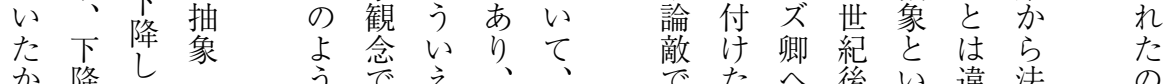

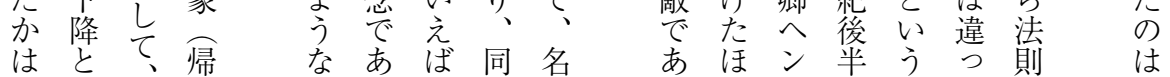




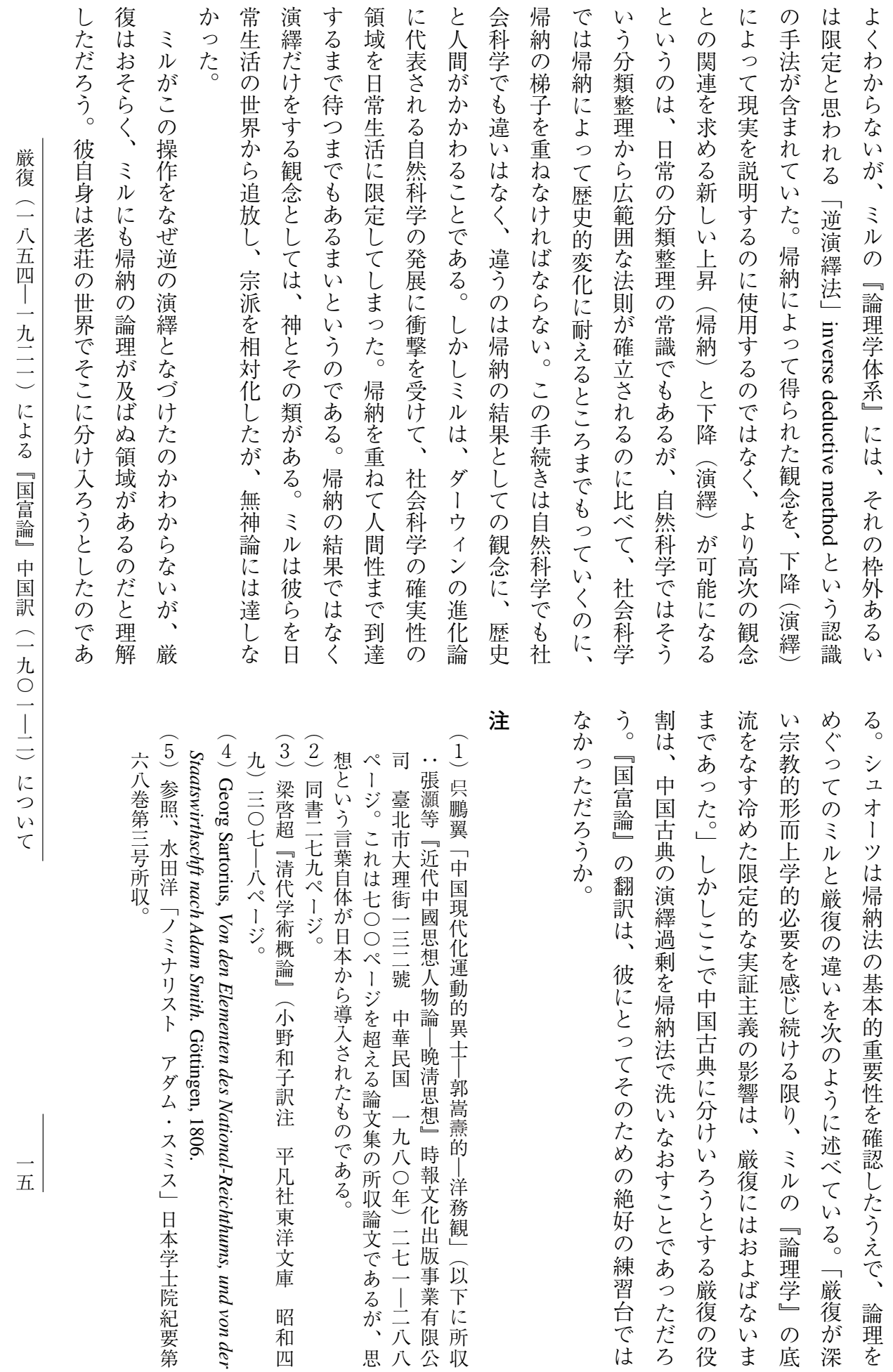




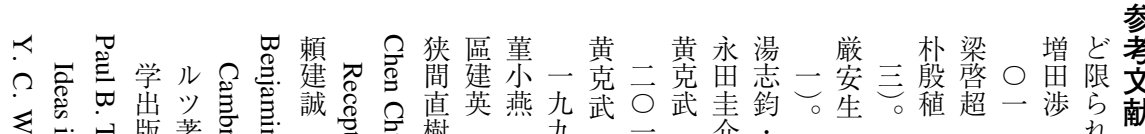

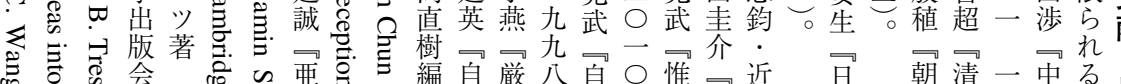

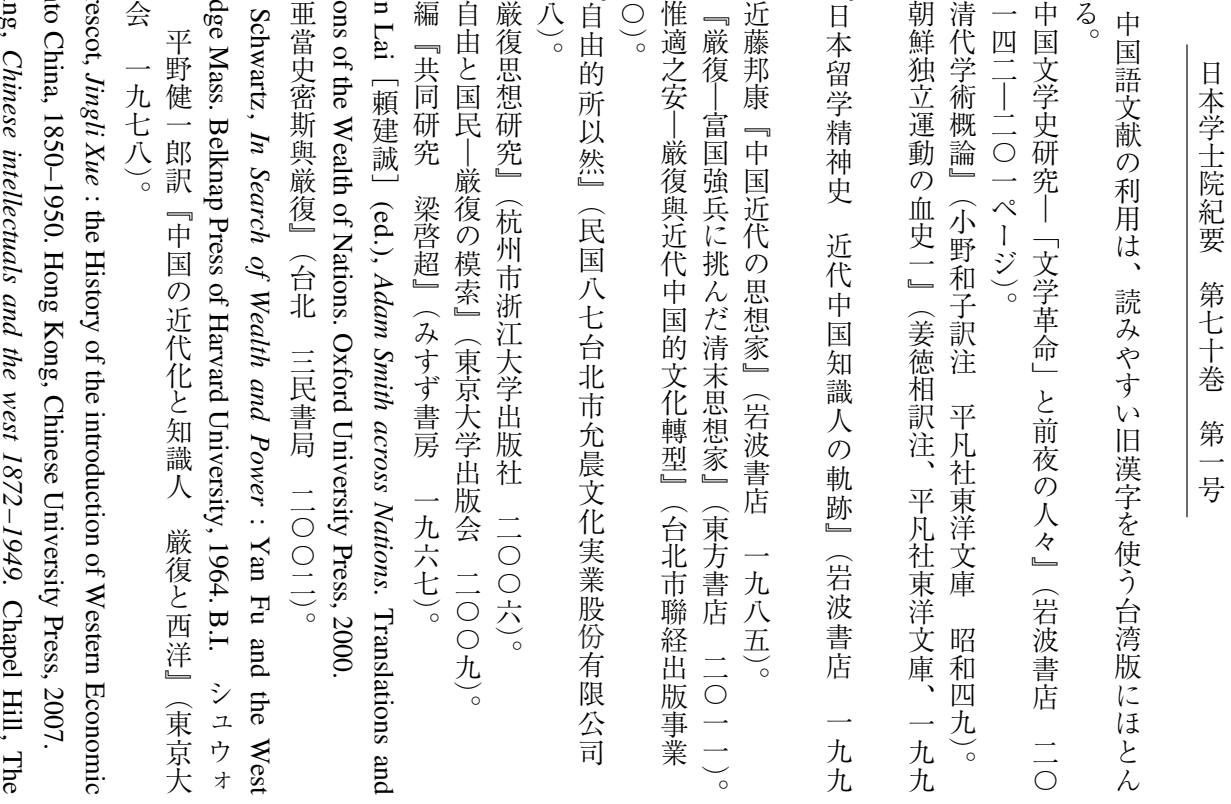

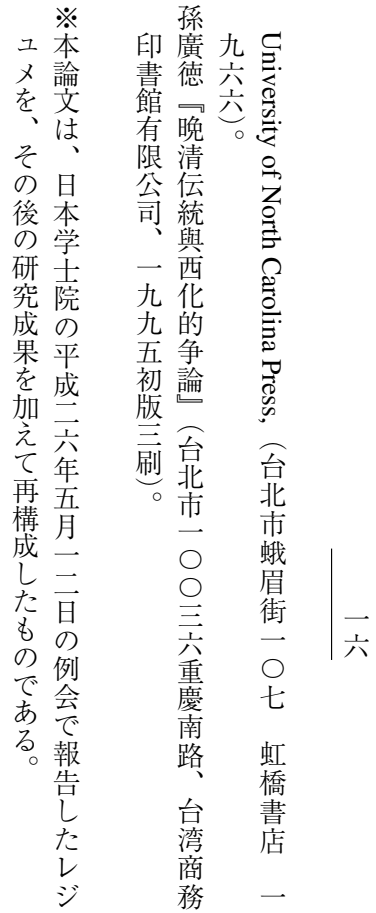


the Greenwich Naval Academy from a local naval school in Fukien in Chinese mainland for the naval training. As a result of his stay in Greenwich and London, and intercourse with Guo Songtao, Yen realized that what matters was not naval power but the western civilization. It is quite probable that Guo told Yen about Inoue's recommendation of the Wealth of Nations which Yen would translate at the turn of the century.

With a change of mind quite similar to the one of Inoue, and having shocked by the defeat of the country in the Sino Japanese war, Yen started press campaign and translation of the western books in 1895. Then he knew Lian Chie-chao as a young colleague for the Chinese bourgeois revolution. But in September 1898, there was a fear of reactionary coup d'état which would make Lian's life risky. But at that very time Ito happened to be in Japanse embassy in Tianjin. Although he was on a private trip, the authority of ex-prime minister enabled him to send Lian to Japan by a Japanese warship. Thus Ito's contribution to the Chinese translation of the Wealth of Nations was quite indirect. But the role of Lian as an intermediater of languages should not be fortgotten. During his stay in exile for more than ten years he mastered Japanese by which he translated Japanese democratic publications, that were originally translated from western languages. He introduced two books on the history of economic thought written by Ingram and Cossa both of which he translated from Japanese translations. They might have been available knowledge of the subject in Chinese when Yen was to start the translation of the Wealth of Naions. 


\title{
The first Chinese translation of the Wealth of Nations with reference to the modernisation of the three nations of East Asia
}

\author{
Hiroshi MizUTA, M. J. A.
}

Sometime in May 1863, during a sort of civil war before the Meiji innovation, a group of five young samurai was sent out on a secret mission from Nagasaki for London. Inoue Kaoru and Ito Hirobumi were among them. They were sent by Choshu clan to which they belonged by birth, and therefore they would be later called "Choshu five". The group was apparently sent to study western civilization but its secret mission was to attain some naval weapons for the cause of "Revere the emperor and expel barbarians". Choshu clan was one of the leading four clans to fight for the cause. Weapons were badly needed to expel barbarians and shogunates. However, at the sight of the flourishing trade port of Shanghigh, Inoue had a radical change of mind that what matters were not weapons but economy and civilization supporting it. On their arrival in London, they discussed the matter and decided that both Inoue and Ito should quickly return home to change the clan's opinion to the liberal side of open doors, even though sea travelling takes more than four months, lest the country should be left behind the general current of history, and that the remaining three should continue their studies in the institutions related to the University College London. Choshu Five is commemorated by a monument in the garden of UCL.

There is no need to describe in detail the brilliant careers of Ito and Inoue as political leaders in the Meiji Innovation. By the leadership of Ito the imperial constitution was proclaimed in 1889. Inoue greatly helped Ito in diplomacy and public finance. In 1878, when Inoue was on leave in London, GuoSongtao who was the first Chinese minister to Britain asked him for any good books in economics to recommend. Inoue recommended Wealth of Nations by Adam Smith and Principles of Political Economy by John Stuart Mill. Guo was a famous admirer of the western civilization and lamented that there was no intellectual group to discuss the problems raised in these books.

However, as a matter of fact, it was about the same time that Yen Fu was sent to 